\title{
Anti-SARS-CoV-2 IgG antibodies after recovery from COVID-19 or vaccination in Libyan population: comparison of four vaccines
}

Fawzi Ebrahim ${ }^{1}$, Salah Tabal ${ }^{1}$, Yosra Lamami ${ }^{1}$, Inas M Alhudiri ${ }^{1}$, Salah Edin El Meshri ${ }^{1}$, Samira M Al Dwigen $^{1}$, Ramadan Arfa ${ }^{2}$, Asma Alboeshi ${ }^{1}$, Hafsa A. Alemam ${ }^{1}$, Fauzia Abuhtna ${ }^{1}$, Rabeeah Altrhouni ${ }^{1}$, Mohamed B Milad ${ }^{1}$, Nada A Elgriw ${ }^{1}$, Mahmoud A Ruaua ${ }^{1}$, Zakarya Abusrewil ${ }^{1}$,Warda Harroush ${ }^{1}$, Mwada Jallul $^{1},{\text { Fouziyah S } \text { Ali }^{1} \text {, Farag Eltaeb }}^{1}$, Adam Elzaghied $^{1}$

${ }^{1}$ Libyan biotechnology Research Center, Tripoli, Libya

2 Information Technology Department, Tripoli University, Libya

1

\begin{abstract}
Background: Natural and vaccine-induced immunity play an important role in controlling the severe acute respiratory syndrome coronavirus 2 (SARS-CoV-2) pandemic. Understanding humoral immunity to SARS-CoV-2 is of great importance for evaluating vaccine performance and inform public health decisions.
\end{abstract}

Objective: We aimed to evaluate the level of IgG antibodies against SARS-CoV-2 and their persistence post infection or post-vaccination.

Methods: A serological analysis (Immunoassay) to investigate the level of anti-spike IgG antibody responses following infection with SARS-CoV-2 or immunization with the first or second dose of the AstraZeneca, Sputnik, Sinovac and Sinopharm vaccines was performed.

Results: A total of 9460 seropositive individuals were recruited. The mean levels of anti-spike IgG antibodies were higher in vaccinated participants with prior COVID-19 infections than in individuals without prior infection. Decline for IgG antibodies were faster in vaccinated individuals without previous COVID-19 infection compared to those with previous COVID-19 infection.

Conclusion: A single dose of the vaccine is likely to provide greater protection against SARS-CoV-2 infection in subjects with prior SARS-CoV-2 infection, than in SARS-CoV-2-naive individuals. In addition, previous COVID-19 infection elicited robust and sustained levels of SARS-CoV-2 antibodies in vaccinated individuals.

Keywords: COVID-19 vaccines, humoral immunity, SARS-CoV-2, antibody titers, spike protein 
medRxiv preprint doi: https://doi.org/10.1101/2022.02.18.22271130; this version posted February 21, 2022. The copyright holder for this preprint (which was not certified by peer review) is the author/funder, who has granted medRxiv a license to display the preprint in perpetuity.

It is made available under a CC-BY-NC-ND 4.0 International license.

\section{Introduction}

SARS-CoV-2, the virus that causes COVID-19 has infected more than 304 million people around the world as of January 9, 2022, causing more than 5.4 million deaths ${ }^{1}$. Both vaccination and herd immunity are important for controlling pandemics ${ }^{2}$. However, the only way to reach herd immunity is by vaccination rather than by natural infection ${ }^{3}$, which makes vaccination crucial ${ }^{2}$. Vaccines stimulate different parts of the immune system, including humoral immunity. Therefore, production of neutralizing antibodies (IgG, IgM) is an indicator of vaccine efficacy. This is also observed after COVID-19 infection ${ }^{5}$. SARS-CoV-2 causes either symptomatic or asymptomatic infection ${ }^{6}$ and induces the production of neutralizing antibodies in most patients ${ }^{7}$ within two weeks after the onset of symptoms ${ }^{8}$. The duration of the humoral immune response and its protective efficacy are still unclear. Several studies have measured the levels of neutralizing antibodies induced by vaccination against SARS-CoV-2, which may play an important role in controlling viral infection ${ }^{9}$. Detection of SARS-CoV-2 antibodies indicates current or past infection ${ }^{10}$. However, the durability of antibody responses and their stability over time remain debatable. Regardless of natural infection or post vaccination. Some studies reported that antibodies did not decline within four months after infection ${ }^{11}$. Others showed rapid decline of antibody levels, their late appearance, and even seronegativity ${ }^{12}$. Some reports estimated that antibodies and memory cells against SARS-CoV-2 persist for at least 4-8 months ${ }^{, 14}$ Another study reported that IgG levels persist for at least nine months after exposure to the virus ${ }^{16}$. So far, the immunity obtained from vaccination is not lifelong or even very long-lasting, but it seems to control the infection to some extent ${ }^{2}$.

In Libya, since the vaccine campaign began in April 2021, four types of vaccines have been administered. According to the National Centre for Disease Control in Libya, more than one million individuals have been vaccinated with the first dose and a total 816,927 second doses have been administered (National Center for Diseases Control, n.d.). Evaluation of immunity after vaccination is important for determining the protection provided by the vaccine. Notably, breakthrough infections may reflect poor post vaccination response. This study evaluated the levels of IgG antibodies against SARS-CoV-2 and their persistence after infection and/or post-vaccination. 
medRxiv preprint doi: https://doi.org/10.1101/2022.02.18.22271130; this version posted February 21, 2022. The copyright holder for this preprint (which was not certified by peer review) is the author/funder, who has granted medRxiv a license to display the preprint in perpetuity.

It is made available under a CC-BY-NC-ND 4.0 International license .

\section{Material and methods}

\section{Participants and study design}

We investigated anti-spike IgG antibody responses following infection with SARS-CoV-2 and/or immunization with the first dose or with two doses of the vaccines in use in Libya. The study was conducted on the Libyan general population in several coastal cities. The study started with initial recruitment of 15,000 participants between August $15^{\text {th }}$ and December $31^{\text {st }} 2021$. The participants were recruited from people visiting healthcare centers and employees in state institutions. The inclusion criterion was age $>18$ years and exclusion criteria were pregnancy, transfusion with blood or plasma during the three months preceding the study, immunosuppressive therapy, recent chemotherapy, autoimmune diseases, and renal dialysis. Blood samples of $3 \mathrm{ml}$ were obtained by venipuncture using Vacutainer tubes. The samples were coded, and serum was separated and stored at $20^{\circ} \mathrm{C}$ until analyzed within 48 hours. The Bioethics Committee at the Biotechnology Research Center in Tripoli (Ref No. approved the study BEC-BTRC 8-2020). The study protocol was compatible with the World Medical Association Declaration of Helsinki (Ethical Principles for Medical Research Involving Human Subjects). All participants provided written informed consent to participate. Those who agreed to participate were given an information sheet detailing the study aim, pledging anonymity of their information, and explaining that they have the right to withdraw from the study at any time. A self-administered questionnaire was used to collect data on sex, age, the type of vaccines received, the date(s) of vaccination, side effects, severity of symptoms, previous Covid-19 infection, and whether the infection (if there was one) was before or after receiving the vaccine. Information on past medical history and influenza vaccination status were also noted.

\section{Detection of SARS-CoV-2 specific serum antibodies}

The Beckman Coulter Access Anti-SARS-CoV-2 IgG assay was used on a UniCel DxI 600 Access Immunoassay System to detect anti-SARS-CoV-2 antibodies according to the manufacturer's instructions (Beckman Coulter, Germany. A sample was considered reactive (positive) for anti-S IgG if the result was $\geq 10 \mathrm{AU} / \mathrm{ml}$. 
medRxiv preprint doi: https://doi.org/10.1101/2022.02.18.22271130; this version posted February 21, 2022. The copyright holder for this preprint (which was not certified by peer review) is the author/funder, who has granted medRxiv a license to display the preprint in perpetuity. It is made available under a CC-BY-NC-ND 4.0 International license.

\section{Statistical analysis}

A web application was developed with PHP, MySQL and JavaScript specifically for electronically collecting survey data and initial statistical analysis. However, the statistical analysis was performed using Microsoft Excel and GraphPad Prism version 9.3. The descriptive statistics included mean, standard deviation and percentages. The differences between mean values were compared by the unpaired Student's t-test. P values $<0.05$ were considered statistically significant.

\section{Results:}

\section{Participant selection and characteristics of study group}

The study was conducted on 9460 individuals, including both symptomatic and asymptomatic recoveries, as well as persons vaccinated with the first dose or with both doses of the vaccine (Figure 1). 


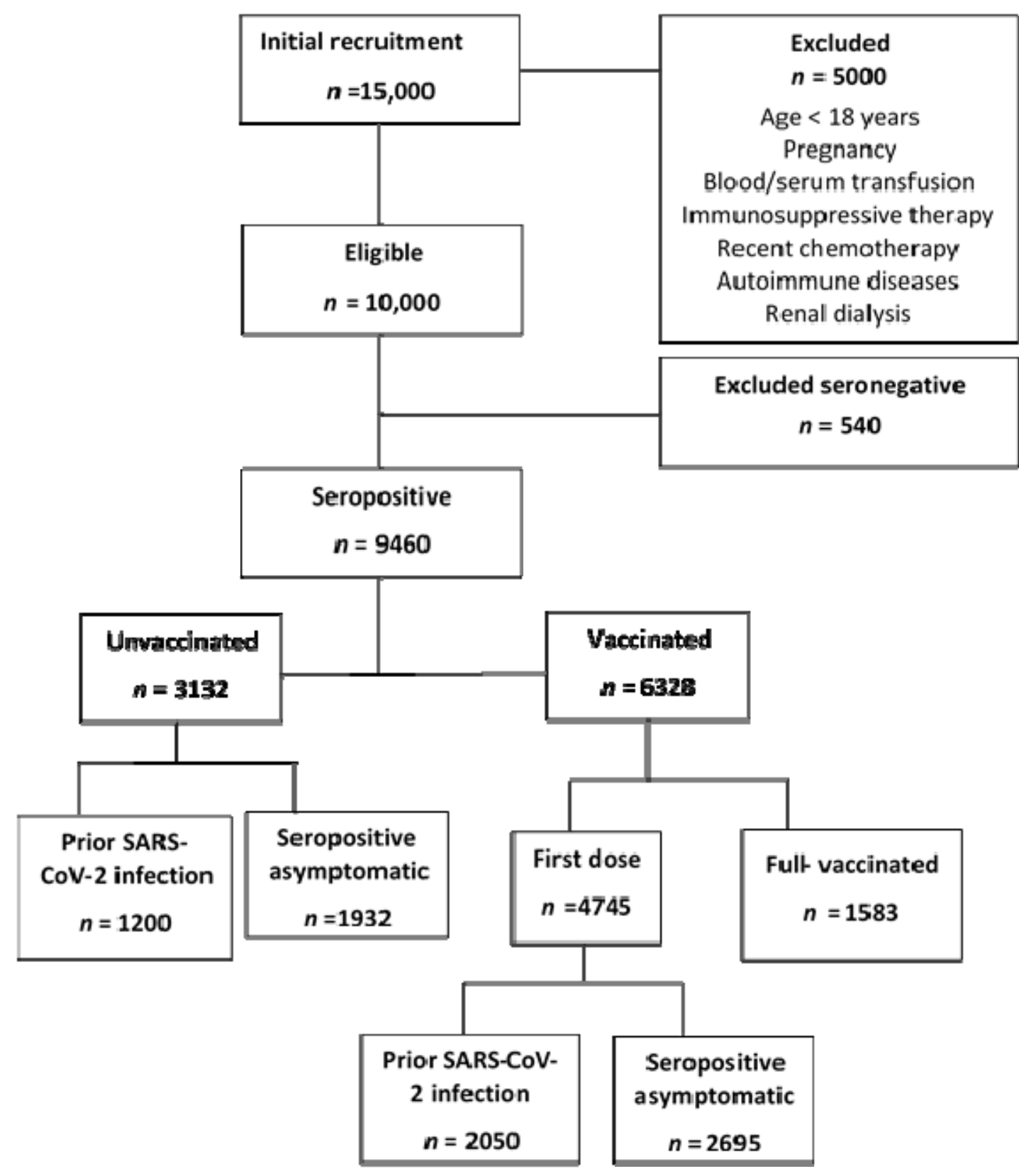

Figure 1. Flowchart showing recruitment and participant selection.

Males represented $54.2 \%$ of the study sample. The ages of the participants ranged from $<35$ to 90 years, and their age distribution is shown in figure 2 . 
Figure 2. Age distribution of the participants

\section{Overall view of vaccinations and seropositivity}

Of the 9640 participants, 6328 had been vaccinated (65.6\%). Of the 3132 unvaccinated individuals who were seropositive, 1200 did not report a previous infection, pointing to a rate of asymptomatic COVID-19 of $38.3 \%$ in this group. The most frequently used vaccines were Sputnik ( $n=4156,65.7 \%$ ) followed by AstraZeneca ( $n=1065,16.7 \%$ ). Only $17.5 \%$ of the participants had been vaccinated with $579 / 6328$ (Table 1). Of the 6328 vaccinated participants, $68.8 \%$ were seropositive. The rate of positivity was lowest for the Sinovac and Sinopharm vaccines (52.2\% and $52.4 \%$, respectively) and considerably higher for the AstraZeneca and Sputnik vaccines (73.8\% and 71.9\%) (Table 1).

Table 1. Distribution of vaccinated participants by sex, vaccine type, and IgG seropositivity

\begin{tabular}{lccccccc}
\hline \multirow{2}{*}{ Vaccine } & \multicolumn{3}{c}{$\mathrm{n}$} & & \multicolumn{2}{c}{ Seropositive } \\
\cline { 2 - 4 } \cline { 6 - 7 } & Females & Males & Total & & $\mathrm{n}$ & $\%$ \\
\hline Sputnik & 1874 & 2282 & 4156 & & 2988 & 71.9 \\
AstraZeneca & 479 & 586 & 1065 & & 786 & 73.8 \\
Sinopharm & 237 & 257 & 494 & & 259 & 52.4 \\
Sinovac & 306 & 307 & 613 & & 320 & 52.2 \\
\hline All vaccines & 2896 & 3432 & 6328 & & 4353 & 68.8 \\
\hline
\end{tabular}


medRxiv preprint doi: https://doi.org/10.1101/2022.02.18.22271130; this version posted February 21, 2022. The copyright holder for this preprint (which was not certified by peer review) is the author/funder, who has granted medRxiv a license to display the preprint in perpetuity.

It is made available under a CC-BY-NC-ND 4.0 International license .

\section{Analysis of seropositivity by age, vaccination status, and prior infection status}

The distribution of seropositivity rates by age group, prior infection status and vaccination status is shown in table 2 . In general, seropositivity rates increased with age. Notably, $100 \%$ of the participants who had been administered one dose, whether previously infected or not, were seropositive, with the exception of those below 35 years of age and had not been previously infected, among whom seropositivity rate was $\mathbf{8 7 . 9 \%}$ (Table 2 ). A dip in positivity rate in the eldest age groups was also noticed in fully vaccinated individuals regardless of infection status (Table 2).

Table 2. Seropositive individuals by age group, vaccination status and prior infection status

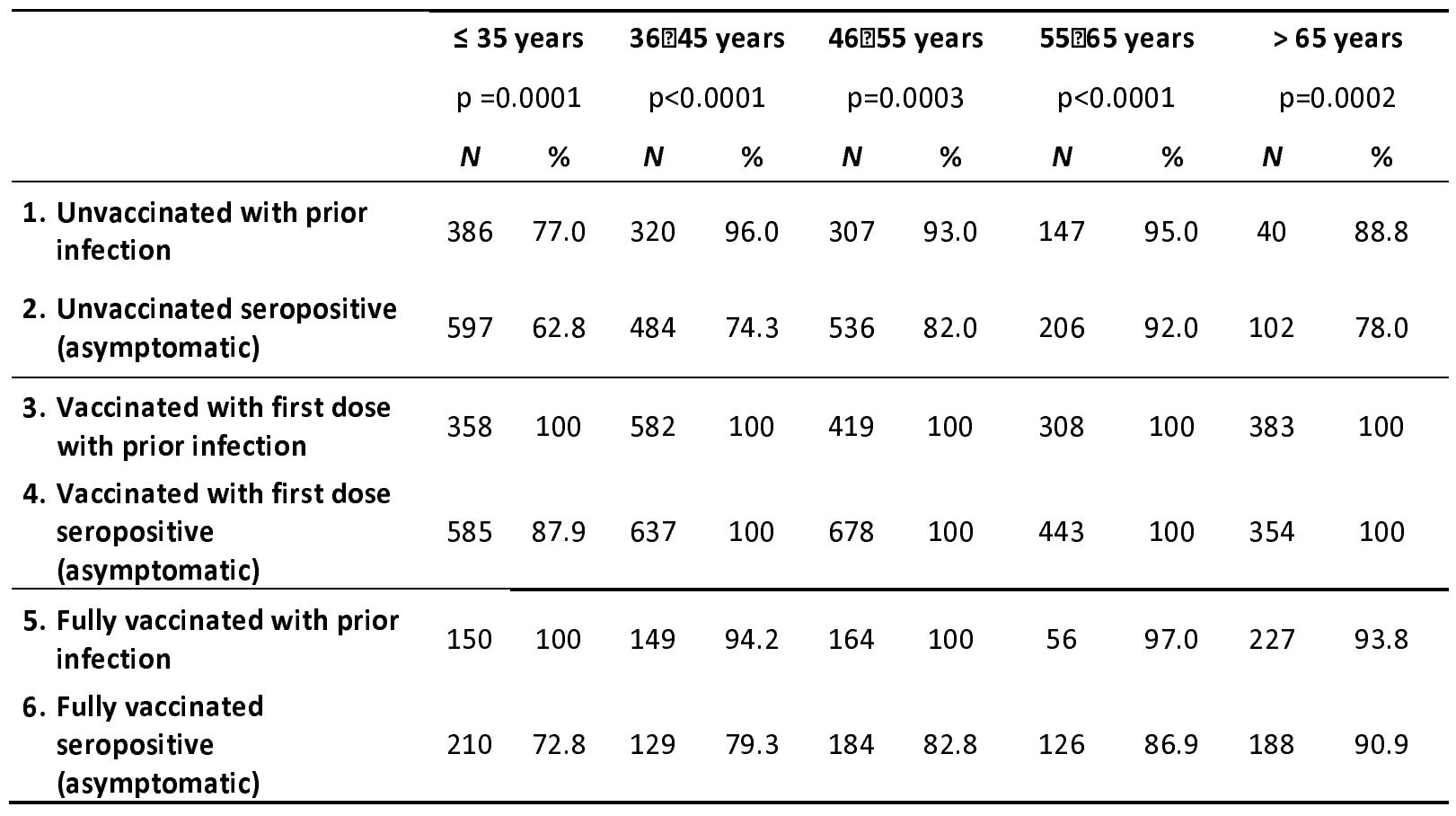

Overall, the seropositivity rate was higher among unvaccinated individuals who reported prior infection (convalescent) than those who did not (asymptomatic) (Table 2). In unvaccinated convalescent individuals, seropositivity was similar in the five age groups, ranging from $77 \%$ ( $\leq 35$ years) to $96 \%$ (36-45 years). In contrast, seropositivity among asymptomatic unvaccinated individuals increased with age from $62.8 \%$ (< 35 years) to $92 \%$ (55-65 years), after which there was a dip to $78 \%$ (Table 2).

Trajectories of IgG levels in previously infected individuals who received one vaccine dose 
From week 1 after vaccination, the mean titers of IgG against the spike protein increased for all vaccines but were considerably higher for the Astra-Zeneca and Sputnik vaccines, which, by week 11, reached 169.2 and 142.0 AU/ml, than for Sinopharm and Sinovac (92.4 and 99.3 AU/ml). However, while the levels against Sputnik and AstraZeneca peaked on week 7 and then started a gradual decline, the IgG levels against Sinovac and Sinopharm continued to rise until week 15, when the levels against the four vaccines became very similar, ranging from $113.6 \mathrm{AU} / \mathrm{ml}$ (Sinopharm) to $123.8 \mathrm{AU} / \mathrm{m}$ (Sputnik) (Figure 2). Thereafter, the rate of decline was more notable for AstraZeneca and Sinopharm. From week 19 to week 21, anti-Sputnik and anti-Sinovac IgG levels were the highest.

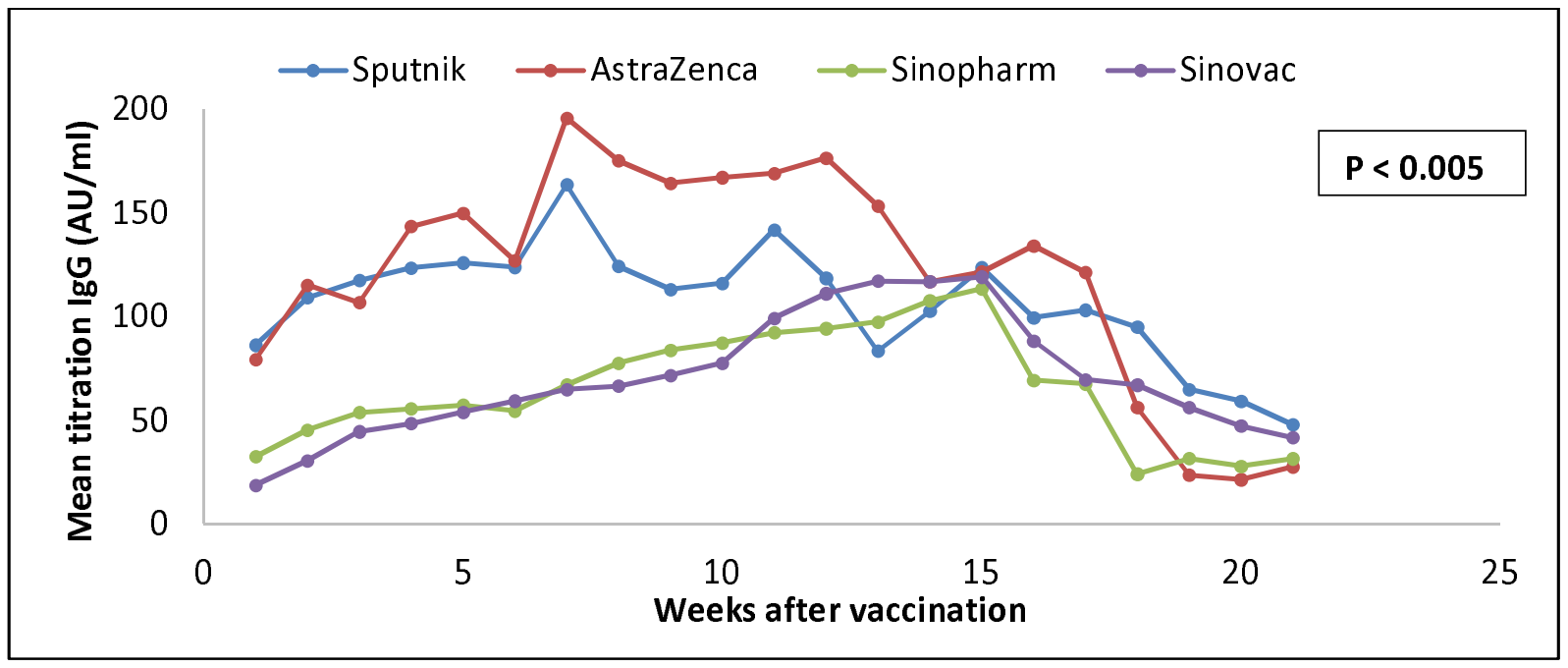

Figure 3. Average anti-spike IgG titers after first vaccination dose in previously infected participants In seropositive participants without evidence of prior infection, post-vaccine antibody responses showed that positive anti-spike IgG results increased over the 3-4 weeks after the first vaccination in case of Sputnik, AstraZeneca and Sinovac respectively (Figure 3). In terms of Sinopharm, the titration began raised over the 5 week. The higher average of titration IgG were observed in Sputnik in week $12(108.36 \mathrm{AU} / \mathrm{ml}$. P value $<0.005)$ while in case of AstraZeneca subjects maximum antibody titration was seen in week 10 (132.67 AU/ml. P < 0.005). The higher titration of seropositive value were (93.7 and $91.05 \mathrm{AU} / \mathrm{ml} . \mathrm{P}<0.005$ ) in Sinopharm and Sinovac respectively. 


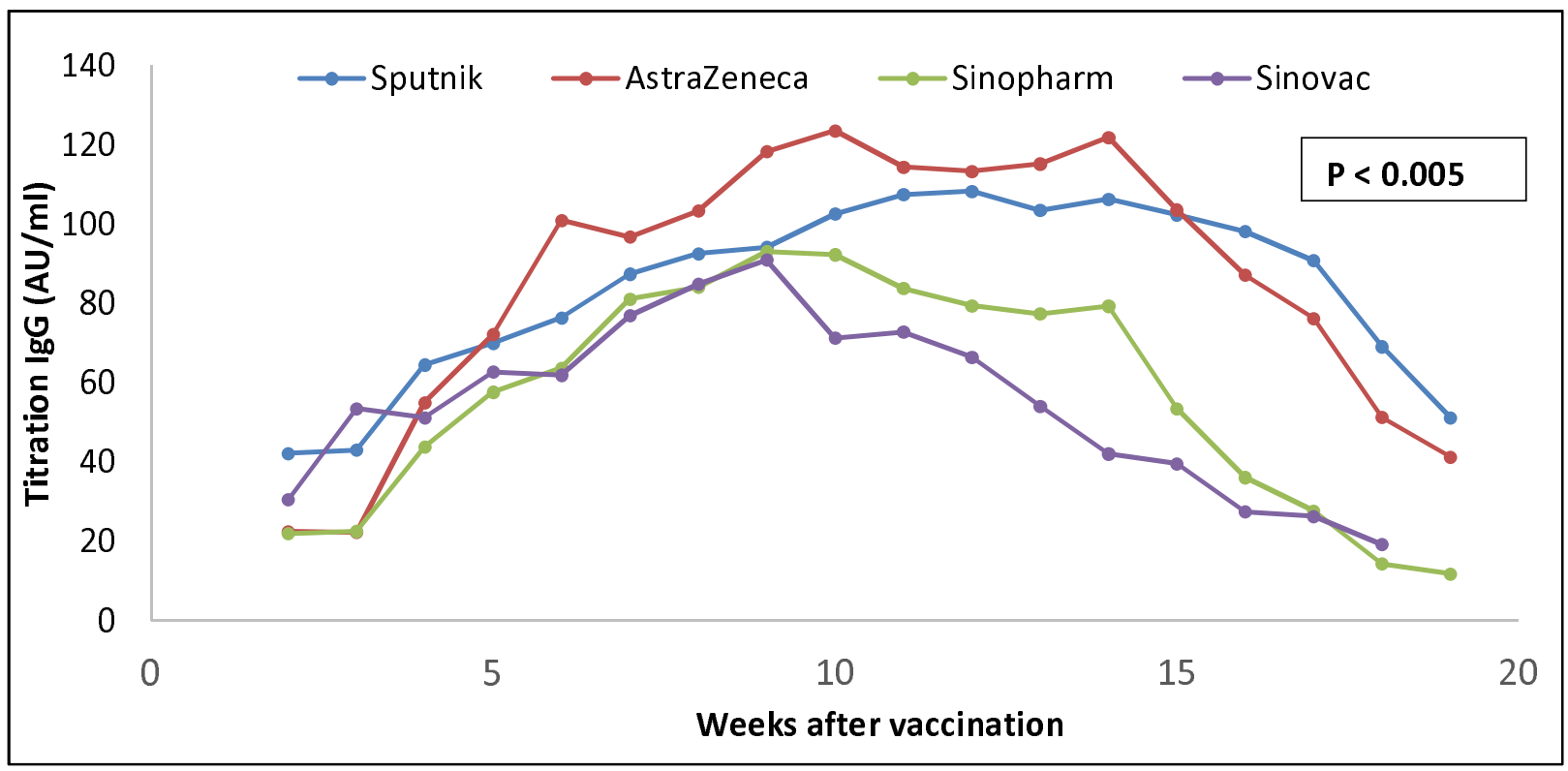

Figure 4. Average anti-spike IgG titers after first vaccination dose in seropositive participants who never had COVID-19 symptoms

In fully vaccinated respondents, the average titers of anti-spike IgG in participants who had received AstraZenca or Spunik vaccine were $257 \mathrm{AU} / \mathrm{ml}$ and $221 \mathrm{AU} / \mathrm{ml}$, respectively ( $\mathrm{p}$ value < 0.005), which is considerably higher than in those who had received only the first dose with or without prior infection (Figure 4). Similar observation were seen in Sinopharm and Sinovac as compared with patients administrated first dose showed in figure 2,3.

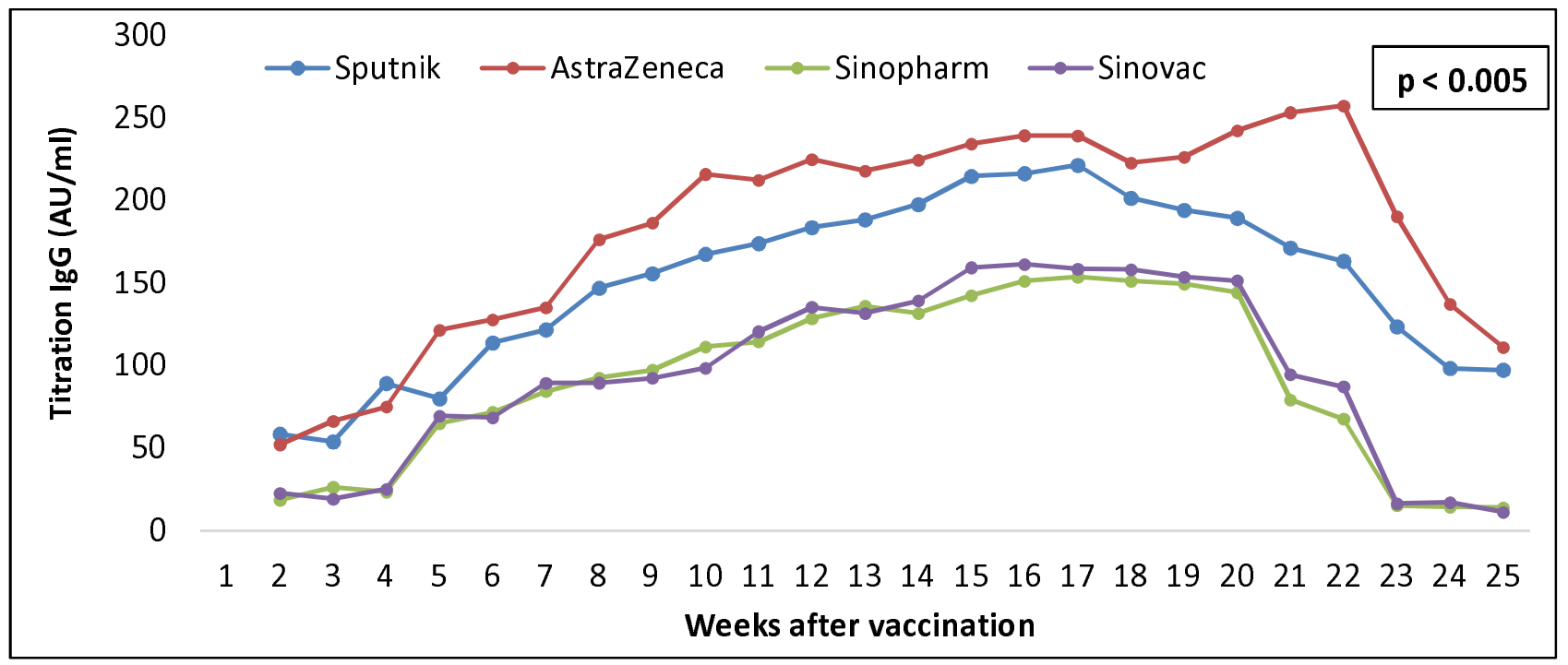


medRxiv preprint doi: https://doi.org/10.1101/2022.02.18.22271130; this version posted February 21, 2022. The copyright holder for this preprint (which was not certified by peer review) is the author/funder, who has granted medRxiv a license to display the preprint in perpetuity.

It is made available under a CC-BY-NC-ND 4.0 International license .

Figure 5. Trajectory of average of anti-spike IgG titers of fully vaccinated individuals (two doses) with or without previous infection.

\section{Discussion}

The main finding of the study is that among the unvaccinated seropositive individuals, $61.7 \%$ had experienced symptoms of the disease while $38.3 \%$ had not. Plebani et al. reported that a strong positive association is being increasingly found between antibodies titers and disease severity, which distinguishes asymptomatic from symptomatic patients ${ }^{18}$. Our results confirm previous findings that prior infection is associated with higher titration of SARS-CoV-2-specific serum-IgG antibodies ${ }^{19}$. Of 9460 participants, 3132 (32\%) were unvaccinated yet seropositive and therefore had been exposed to SARS-Cov2 infection. 1932 participants were asymptomatic. Furthermore, that asymptomatic and mildly ill participants seem to produced low levels of antibody-mediated immunity has important implications for understanding herd immunity ${ }^{12}$. In addition, subjects individuals vaccinated with first dose with prior COVID-19 infection (natural immunity) significantly higher titration IgG than first dosevaccinated individuals without prior infection (acquired immunity) ${ }^{20}$. Further, the current results support the observation that infected vaccinated participants showed higher mean titration than uninfected vaccinated first dose only ${ }^{21}$. Moreover, our finding states that in SARS-CoV-2 naturally infected individuals a single vaccine dose seems sufficient to reach immunity. We also found that a single-dose of "Sputnik Light" vaccine formed a faster humoral immune response in seropositive participants had previous infection, same finding published by Tukhvatulin et al $2021^{22}$. Tretyn et al status that, primary humoral immunity, one of the indicators of which is the presence of IgG antibodies, appeared 2 weeks post administrating the mRNA vaccine ${ }^{23} 24$. Same result obtained in our study, IgG triggered since 2 weeks particularly in patients received first dose without prior infection in all vaccines type involved in our study. Based on these results, one can assume that a prior SARS-CoV-2 infection triggered the immune system to a very strong response to a single dose of the vaccine. The first dose, given in to individuals whose immune systems previously stimulated by the natural infection, had a similar effect when given as a second "booster" dose. Our observations are consistent with the studies of Voysey et al. who published data demonstrated that in subjects who immunized after natural COVID-19 infection, antibody responses after the first dose of 
medRxiv preprint doi: https://doi.org/10.1101/2022.02.18.22271130; this version posted February 21, 2022. The copyright holder for this preprint (which was not certified by peer review) is the author/funder, who has granted medRxiv a license to display the preprint in perpetuity.

It is made available under a CC-BY-NC-ND 4.0 International license.

AstraZeneca vaccine were higher than in participants without prior infection ${ }^{25}$. In light with the increased demand and shortage of vaccine supply, this finding would support implementing a strategy of a single vaccine dose for individuals who were previously infected by SARS-CoV-2. Furthermore, respondents fully-vaccinated individuals with or without previous COVID-19 infection showed highly titration value in terms of AstraZeneca and sputnik $239 \mathrm{AU} / \mathrm{ml}$ and $221 \mathrm{AU} / \mathrm{ml}$ in week 17 respectively. IgG against COVID-19 exist detected until 24 week, which consider long duration as compared with subjects, received on dose. Two vaccine doses achieved high responses across all age groups, and particularly increased $\mathrm{r}$ people seroconverting to similar levels to those receiving one dose after prior infection ${ }^{26}$. Wei et al confirmed that, significantly increased seropositivity and antibody levels in participants received two vaccine dose ${ }^{27}$. The decline in IgG levels over time was expected since this occurs for all vaccines types involving in the current study. The serological analysis in this study was performed an average of five months post vaccination. This finding agreed with previous published data showing that antibodies detected for several months after vaccination ${ }^{28}$. Additionally, in vaccinated individuals, IgG levels were maintained for longer times in those who were previously infected than in those who were not ${ }^{2129}$.

Interestingly, this type of response is present whether individuals developed a symptomatic COVID-19 disease. These observations are in line with the hypothesis that the first vaccine dose serves as a boost in naturally infected individuals ${ }^{29}$. Our findings have important implications for vaccination policy. In light of the growing demand and shortage of vaccine production, this finding would support implementing a strategy of a single vaccine dose for persons who were previously infected by SARSCoV-2. Although we are expected that the continuing vaccination campaign should provide some control of disease, spread and reduce the degree of mortality and morbidity rate among population, but will not prevent the spread of infection. The findings of the current study have some limitations. First, the study did not include children and immunocompromised adults. Furthermore, most fully vaccinated participants did not receive the second dose on schedule, which could reflect on the accuracy of results.

\section{Conclusion}

In summary, detectable SARS-CoV-2, anti-spike IgG levels among unvaccinated individuals due to previous infection either if the symptomatic and asymptomatic showed the good immunity status for 
medRxiv preprint doi: https://doi.org/10.1101/2022.02.18.22271130; this version posted February 21, 2022. The copyright holder for this preprint (which was not certified by peer review) is the author/funder, who has granted medRxiv a license to display the preprint in perpetuity.

It is made available under a CC-BY-NC-ND 4.0 International license .

individuals. Vaccination with prior COVID-19 infection demonstrated higher IgG titration than vaccination without prior infection. The persistence of spike antigen-specific serum IgG following vaccination is hopefully a positive indicator of effective long-lived immunity, and clinical indicator of vaccine efficacy. Our results suggest that even greater efforts should be made to immunize more individual, particularly people without prior COVID-19 infection. However, further investigations are needed to estimate the maintenance of these immune responses and the potential need for booster doses.

\section{Author contributions}

Study Conception and design: $A E, F E, I A$ and $Z A$. YL, SD, WH, HE, NG, FM, FS, RT, ME and MA performed the antibody titer tests. RA, ST and FE analyzed the data. MJ and FE wrote the introduction, YA wrote the methods, FE wrote the results and discussion. AZ, FE IA finalized the manuscript. All authors had full access to all the data in the study, reviewed the final manuscript, and approved its submission for publication.

\section{Acknowledgements}

The authors thank the Ministry of Health and the Libyan Authority for Scientific Research. We also thank all the health care workers for their valuable work in blood sampling. In addition, we thank the study participants for their support of COVID-19 research.

\section{Conflict of interest}

The authors declare that they have no conflict of interest.

\section{References}

1. WHO. COVID-19 weekly epidemiological update. World Heal Organ. 2021;(58):1-23. https://www.who.int/publications/m/item/covid-19-weekly-epidemiological-update

2. Yoo J-H. What We Do Know and Do Not Yet Know about COVID-19 Vaccines as of the Beginning of the Year 2021. J Korean Med Sci. 2021;36(6). doi:10.3346/jkms.2021.36.e54

3. Jones D, Helmreich S. A history of herd immunity. Lancet. 2020;396(10254):810-811. doi:10.1016/S0140-6736(20)31924-3

4. Rasmussen AL. Vaccination Is the Only Acceptable Path to Herd Immunity. Med. 2020;1(1):2123. doi:10.1016/j.medj.2020.12.004

5. Long Q-X, Tang X-J, Shi Q-L, et al. Clinical and immunological assessment of asymptomatic 
medRxiv preprint doi: https://doi.org/10.1101/2022.02.18.22271130; this version posted February 21, 2022. The copyright holder for this preprint (which was not certified by peer review) is the author/funder, who has granted medRxiv a license to display the preprint in perpetuity. It is made available under a CC-BY-NC-ND 4.0 International license .

SARS-CoV-2 infections. Nat Med. 2020;26(8):1200-1204. doi:10.1038/s41591-020-0965-6

6. Altawalah H. Antibody Responses to Natural SARS-CoV-2 Infection or after COVID-19 Vaccination. Vaccines. 2021;9(8):910. doi:10.3390/vaccines9080910

7. Iyer AS, Jones FK, Nodoushani A, et al. Persistence and decay of human antibody responses to the receptor binding domain of SARS-CoV-2 spike protein in COVID-19 patients. Sci Immunol. 2020;5(52). doi:10.1126/sciimmunol.abe0367

8. Zhao J, Yuan Q, Wang H, et al. Antibody Responses to SARS-CoV-2 in Patients With Novel Coronavirus Disease 2019. Clin Infect Dis. 2020;71(16):2027-2034. doi:10.1093/cid/ciaa344

9. Hodgson SH, Mansatta K, Mallett G, Harris V, Emary KRW, Pollard AJ. Si the COVID-19 resource centre - including this for unrestricted research re-use a. 2020;(January).

10. Dinnes J, Deeks JJ, Adriano A, et al. Rapid, point-of-care antigen and molecular-based tests for diagnosis of SARS-CoV-2 infection. Cochrane Database Syst Rev. 2020;2020(8). doi:10.1002/14651858.CD013705

11. Gudbjartsson DF, Norddahl GL, Melsted P, et al. Humoral Immune Response to SARS-CoV-2 in Iceland. N Engl J Med. 2020;383(18):1724-1734. doi:10.1056/NEJMoa2026116

12. Jeyanathan M, Afkhami S, Smaill F, Miller MS, Lichty BD, Xing Z. Immunological considerations for COVID-19 vaccine strategies. Nat Rev Immunol. 2020;20(10):615-632. doi:10.1038/s41577020-00434-6

13. Widge AT, Rouphael NG, Jackson LA, et al. Durability of Responses after SARS-CoV-2 mRNA1273 Vaccination. N Engl J Med. 2021;384(1):80-82. doi:10.1056/NEJMc2032195

14. L'Huillier AG, Meyer B, Andrey DO, et al. Antibody persistence in the first 6 months following SARS-CoV-2 infection among hospital workers: a prospective longitudinal study. Clin Microbiol Infect. 2021;27(5):784.e1-784.e8. doi:10.1016/j.cmi.2021.01.005

15. Dan JM, Mateus J, Kato Y, et al. Immunological memory to SARS-CoV-2 assessed for up to 8 months after infection. Science (80- ). 2021;371(6529). doi:10.1126/science.abf4063

16. He Z, Ren L, Yang J, et al. Seroprevalence and humoral immune durability of anti-SARS-CoV-2 antibodies in Wuhan, China: a longitudinal, population-level, cross-sectional study. Lancet. 2021;397(10279):1075-1084. doi:10.1016/S0140-6736(21)00238-5

17. Natinal Center for Diseases Control L. إجمالي عدد المطعمين.

18. Plebani M, Padoan A, Negrini D, Carpinteri B, Sciacovelli L. Diagnostic performances and thresholds: The key to harmonization in serological SARS-CoV-2 assays? Clin Chim Acta. 2020;509:1-7. doi:10.1016/j.cca.2020.05.050

19. Ma H, Zeng W, He H, et al. Serum IgA, IgM, and IgG responses in COVID-19. Cell Mol Immunol. 2020;17(7):773-775. doi:10.1038/s41423-020-0474-z

20. Callegaro A, Borleri D, Farina C, et al. Antibody response to SARS-CoV-2 vaccination is extremely vivacious in subjects with previous SARS-CoV-2 infection. J Med Virol. 2021;93(7):4612-4615. 
medRxiv preprint doi: https://doi.org/10.1101/2022.02.18.22271130; this version posted February 21, 2022. The copyright holder for this preprint (which was not certified by peer review) is the author/funder, who has granted medRxiv a license to display the preprint in perpetuity. It is made available under a CC-BY-NC-ND 4.0 International license .

doi:10.1002/jmv.26982

21. Ali H, Alahmad B, Al-Shammari AA, et al. Previous COVID-19 Infection and Antibody Levels After Vaccination. Front Public Heal. 2021;9(December):1-11. doi:10.3389/fpubh.2021.778243

22. Tukhvatulin Al, Dolzhikova I V., Shcheblyakov D V., et al. An open, non-randomised, phase 1/2 trial on the safety, tolerability, and immunogenicity of single-dose vaccine "Sputnik Light" for prevention of coronavirus infection in healthy adults. Lancet Reg Heal - Eur. 2021;11. doi:10.1016/j.lanepe.2021.100241

23. Tretyn A, Szczepanek J, Skorupa M, et al. Differences in the concentration of anti-sars-cov- 2 igg antibodies post-covid-19 recovery or post-vaccination. Cells. 2021;10(8). doi:10.3390/cells10081952

24. Saadat S, Rikhtegaran Tehrani Z, Logue J, et al. Binding and Neutralization Antibody Titers After a Single Vaccine Dose in Health Care Workers Previously Infected With SARS-CoV-2. JAMA. 2021;325(14):1467-1469. doi:10.1001/JAMA.2021.3341

25. Voysey M, Clemens SAC, Madhi SA, et al. Safety and efficacy of the ChAdOx1 nCoV-19 vaccine (AZD1222) against SARS-CoV-2: an interim analysis of four randomised controlled trials in Brazil, South Africa, and the UK. Lancet. 2021;397(10269):99-111. doi:10.1016/S01406736(20)32661-1

26. Ebinger JE, Fert-Bober J, Printsev I, et al. Antibody responses to the BNT162b2 mRNA vaccine in individuals previously infected with SARS-CoV-2. Nat Med. 2021;27(6):981-984. doi:10.1038/S41591-021-01325-6

27. Wei J, Stoesser N, Matthews PC, et al. Antibody responses to SARS-CoV-2 vaccines in 45,965 adults from the general population of the United Kingdom. Nat Microbiol. 2021;6(9):11401149. doi:10.1038/s41564-021-00947-3

28. Naaber P, Tserel L, Kangro K, et al. Dynamics of antibody response to BNT162b2 vaccine after six months: a longitudinal prospective study. Lancet Reg Heal - Eur. 2021;10. doi:10.1016/j.lanepe.2021.100208

29. Vicenti I, Gatti F, Scaggiante R, et al. Single-dose BNT162b2 mRNA COVID-19 vaccine significantly boosts neutralizing antibody response in health care workers recovering from asymptomatic or mild natural SARS-CoV-2 infection. Int J Infect Dis. 2021;108:176-178. doi:10.1016/j.ijid.2021.05.033 